Southern Illinois University Carbondale

OpenSIUC

Publications

Fisheries and Illinois Aquaculture Center

$7-2006$

\title{
Comparison of Pond Production of Phase-III Sunshine Bass Fed 32-, 36-, and 40\%-Crude- Protein Diets with Fixed Energy : Protein Ratios
}

James E. Wetzel

Craig S. Kasper

Christopher C. Kohler

Southern Illinois University Carbondale

Follow this and additional works at: http://opensiuc.lib.siu.edu/fiaq pubs

(c) by the American Fisheries Society 2006

Published in North American Journal of Aquaculture, Vol. 68, Issue 3 (July 2006) at doi: 10.1577/

A05-044.1

\section{Recommended Citation}

Wetzel, James E., Kasper, Craig S. and Kohler, Christopher C. "Comparison of Pond Production of Phase-III Sunshine Bass Fed 32-, 36-, and 40\%-Crude-Protein Diets with Fixed Energy : Protein Ratios." (Jul 2006).

This Article is brought to you for free and open access by the Fisheries and Illinois Aquaculture Center at OpenSIUC. It has been accepted for inclusion in Publications by an authorized administrator of OpenSIUC. For more information, please contact opensiuc@lib.siu.edu. 


\title{
Comparison of Pond Production of Phase-III Sunshine Bass Fed 32-, 36-, and 40\%-Crude-Protein Diets with Fixed Energy : Protein Ratios
}

\author{
James E. Wetzel, Craig S. Kasper, and Christopher C. Kohler* \\ Fisheries and Illinois Aquaculture Center, Southern Illinois University-Carbondale, \\ Carbondale, Illinois 62901-6511, USA
}

\begin{abstract}
We stocked phase-III sunshine bass (white bass Morone chrysops $q \times$ striped bass $M$. saxatilis ऽ) at a rate of 6,188 fingerlings/ha into twelve 0.04-ha earthen ponds supplied with continuous aeration. Three dietary treatments were randomly assigned to quadruplicate ponds. Sunshine bass were fed to apparent satiation once daily after average initial weight (mean $\pm \mathrm{SE}=214 \pm 5 \mathrm{~g})$ and total length $(245 \pm 1.6 \mathrm{~mm})$ were determined. Diets were formulated to conserve the estimated digestible energy : crude protein $(\mathrm{CP})$ ratio (9.3 kcal/g protein) and represented the following CP and energy values fed to fish: $32 \% \mathrm{CP}(3,000 \mathrm{kcal} / \mathrm{kg})$, $36 \% \mathrm{CP}(3,360 \mathrm{kcal} / \mathrm{kg})$, and $40 \% \mathrm{CP}(3,760 \mathrm{kcal} / \mathrm{kg})$. Harvest data suggest that nutrient density is a variable that can be manipulated to optimize production and reduce production costs. Production rates (mean $\pm \mathrm{SE}$ ) were $2,851 \pm 600 \mathrm{~kg} / \mathrm{ha}$ for the $32 \%$-CP diet, $2,895 \pm 341 \mathrm{~kg} / \mathrm{ha}$ for the $36 \%$-CP diet, and 2,953 $\pm 142 \mathrm{~kg} /$ ha for the $40 \%$-CP diet; production rates were not significantly different among dietary treatments. Survival was excellent and did not appear to be related to dietary treatment. Dressed (gilled and gutted) fish averaged $80 \%$ of whole-fish weight, and the dressed percentage did not vary as a function of nutrient density. Feed conversion ratios of $3.0 \pm 0.4,2.8 \pm 0.2$, and $2.6 \pm 0.1$ were obtained for the fish fed 32-, 36-, and $40 \%-\mathrm{CP}$ diets, respectively. Protein conversion ratios (mean $=1.0$ ) were not significantly influenced by dietary treatment. Feed cost increased with increasing dietary CP level; costs were US $\$ 0.447$ per kilogram for the $32 \%$-CP diet, $\$ 0.493$ per kilogram for the 36\%-CP diet, and \$0.541 per kilogram for the 40\%-CP diet. The resulting production costs attributable to feed were $\$ 1.34, \$ 1.38$, and $\$ 1.41$ per kilogram of gain for the 32-, $36-$, and $40 \%-\mathrm{CP}$ diets, respectively. A savings of $\$ 0.16$ per kilogram produced, or approximately $\$ 450$ per hectare, was realized as a result of feeding either of the two lower-CP, lower-energy diets. Accordingly, we suggest that phase-III sunshine bass can be more economically produced by feeding diets as low as $32 \% \mathrm{CP}$ with a minimum energy : protein ratio of $9.3 \mathrm{kcal} / \mathrm{g} \mathrm{CP}$.
\end{abstract}

Production of sunshine bass (white bass Morone chrysops $+\times$ striped bass $M$. saxatilis $\widehat{\delta})$ as a food fish continues to develop rapidly as an industry in the United States. Sunshine bass production consists of three phases: phase I (4-d posthatch larvae to $\sim 1.0-\mathrm{g}$ fingerling), phase II $(\sim 1.0-\mathrm{g}$ fingerling to $\sim 100 \mathrm{-g}$ juvenile), and phase III $(\sim 100-\mathrm{g}$ juvenile to $\sim 650$-g market-size fish). The cost of feed generally represents one of the largest variable expenses incurred during intensive production of phase-III sunshine bass. Within that category, variations in levels and sources of dietary protein affect cost and production significantly. Therefore, the determination of the requirement for protein and the optimum energy to protein $(\mathrm{E}: \mathrm{P})$ ratio has been addressed repeatedly; however, the potential use of fixed amino acid profiles and E:P ratios has not received similar attention under intensive culture conditions with phase-III fish.

Many diets used in production of sunshine bass are

\section{* Corresponding author: ckohler@siu.edu}

Received April 21, 2005; accepted October 26, 2005 Published online June 12, 2006 still formulated according to nutrient requirements for juvenile salmonids (NRC 1993). Such formulations are extremely energy dense with respect to adult sunshine bass requirements. It has been suggested that during phase III, sunshine bass may be reared on significantly lower amounts of dietary protein and energy than are indicated by results of previous research (Nematipour and Gatlin 1992a, 1992b; Brown et al. 1993; NRC 1993; Kasper and Kohler 2004). Requirements for protein and optimum energy : crude protein $(\mathrm{CP})$ ratios (kcal of energy/g CP) have been evaluated in small sunshine bass (Sullivan and Reigh 1995; Webster et al. 1995); however, similar studies considering protein reduction as a result of fixing amino acid profiles and simultaneously reducing energy and that use phase-III fish have not been performed. Utilization of diets wherein similar amino acid profiles are maintained will probably provide for greater control than the use of diets with highly variable amino acid profiles, as is often the case in studies where the reduction of protein and/or energy is considered exclusively. Application of this formulation strategy may permit reductions in dietary protein while still maintaining optimal growth 
and feed efficiency and consequently lowering overall feed costs. Therefore, the objective of this study was to compare production characteristics of phase-III sunshine bass fed diets that contained 32,36 , or $40 \% \mathrm{CP}$ and $3,000,3,360$, or $3,760 \mathrm{kcal} / \mathrm{kg}$ feed, respectively, and that possessed fixed E:P ratios.

\section{Methods}

Fish husbandry.-Sunshine bass reared in vertical raceways at the Southern Illinois University-Carbondale pond complex until the onset of phase III (see Volkman et al. 2004) were stocked on 8 March 2002 into 0.04-ha ponds $(n=12)$ at a density of 6,188 fish/ ha. Ponds were aerated continuously by use of 1-hp paddle-wheel aerators. Fish were initially fed a trout grower diet (3 mm; Silvercup, Murray, Utah) containing $40 \% \mathrm{CP}$ once daily at a rate of $0.5 \%$ body weight for 10 weeks. After this acclimation period, a 50-fish subsample was removed from each pond to determine initial total length (TL) in millimeters and weight $(W)$ in grams for calculation of condition factor $(K=W /$ $\mathrm{TL}^{3}$; Table 1). The samples of fish were then returned to their respective ponds. Four ponds were randomly assigned to each of three dietary treatments, and the study was initiated. Fish were fed once daily to satiation until harvest on 18 November 2002. The amount of feed consumed was recorded daily. During the study, water temperature and dissolved oxygen were measured daily at 0800 hours by use of a YSI Model 55 dissolved oxygen meter (Yellow Springs Instruments, Inc., Yellow Springs, Ohio); total ammonia-nitrogen, nitrite-nitrogen, $\mathrm{pH}$, alkalinity, and total hardness were determined from weekly water samples with a LaMotte AQ-2 water quality test kit (LaMotte, Chestertown, Maryland). Dissolved oxygen, ammonianitrogen, and nitrite-nitrogen did not exceed recommended parameters for culture of sunshine bass (Kohler 2000). Water pH averaged 6.8, while alkalinity and total hardness remained above $60 \mathrm{mg} / \mathrm{L}$.

Experimental diets and diet manufacturing.-Experimental diets used in this study were formulated to meet or exceed the known protein and energy requirements of hybrid striped bass (Griffin et al. 1992;
Keembiyehetty and Gatlin 1992; Nematipour and Gatlin 1992a, 1992b; Griffin et al. 1994a, 1994b, 1994c; Brown 1995; Gallagher 1997). Three experimental floating diets (diets 1-3) were mixed by Land O'Lakes Feed (Kansas City, Missouri) and were formulated to contain 32, 36, or $40 \% \mathrm{CP}$ and 3,000, 3,360 , or $3,760 \mathrm{kcal} / \mathrm{kg}$ feed, respectively (Tables 2, 3), resulting in a consistent $\mathrm{E}: \mathrm{P}$ ratio of $9.3 \mathrm{kcal} / \mathrm{g} \mathrm{CP}$ following formulations similar to those of Nematipour et al. (1992a). Diets used in this study were extruded by Wenger (Sabetha, Kansas). Experimental diets were refrigerated until use.

Sample collection.-After the feeding trial, all fish from each pond were weighed in bulk and counted individually to determine production. Additionally, a random sample of 50 fish was collected from each pond; each of these fish was individually weighed (nearest $\mathrm{g}$ ) and measured for $\mathrm{TL}$ (nearest $\mathrm{mm}$ ) for calculation of $K$. Also, 25 fish were randomly removed from each pond and were dressed (gilled and gutted). Total feed consumption for the duration of the study was determined for each pond for use in calculating the feed conversion ratio.

Statistical analysis.-Data were analyzed in a completely randomized design wherein each pond was the experimental unit. The accepted level of significance was 0.05. All statistical analyses were performed in the Statistical Analysis System (SAS Institute, Cary, North Carolina). If significant differences were detected by analysis of variance, then the Student-Newman-Keul's test was used to separate treatment means.

\section{Results}

Total production rates (mean $\pm \mathrm{SE}$ ) were $2,851 \pm$ $300,2,895 \pm 96$, and 2,953 $\pm 71 \mathrm{~kg} / \mathrm{ha}$ (Table 4) and total harvest rates (mean $\pm \mathrm{SE}$ ) were 4,202 \pm 205 , $4,253 \pm 195$, and $4,178 \pm 24 \mathrm{~kg} /$ ha (Table 5) for the 32-, 36-, and 40\%-CP diets, respectively; these variables were not significantly different among treatments. Percent survival (mean \pm SE) was $93 \pm 5,88$ \pm 4 , and $90 \% \pm 1 \%$ for the fish fed 32-, 36-, and 40\%-CP diets, respectively, and did not significantly differ among treatments (Table 3). Individual fish

TABLE 1.- Mean initial weight, initial length, stocking weight, and condition factor $(K)$ of sunshine bass fed 32-, 36-, and $40 \%$-crude-protein (CP) diets with an energy : protein ratio of $9.3 \mathrm{kcal}$ energy/g CP. Values $(n=50)$ are means $( \pm \mathrm{SEs})$ of four ponds. Means within each column are not significantly different $(P<0.05)$.

\begin{tabular}{ccccccc}
\hline $\begin{array}{c}\% \text { CP } \\
(\mathrm{kcal} \text { energy/kg) }\end{array}$ & $\begin{array}{c}\text { Initial weight } \\
(\mathrm{kg} / \mathrm{ha})\end{array}$ & $\begin{array}{c}\text { Initial length } \\
(\mathrm{mm})\end{array}$ & $\begin{array}{c}\text { Pond weight at } \\
\text { stocking }(\mathrm{kg} / \mathrm{ha})\end{array}$ & $\begin{array}{c}\text { Final individual } \\
\text { weight }(\mathrm{g} / \mathrm{fish})\end{array}$ & Initial $K^{\mathrm{a}}$ & Final $K^{\mathrm{a}}$ \\
\hline $32(3,000)$ & $216 \pm 23$ & $245 \pm 8$ & $1,350 \pm 63$ & $726 \pm 20$ & $1.46 \pm 0.03$ & $1.92 \pm 0.01$ \\
$36(3,360)$ & $217 \pm 27$ & $247 \pm 8$ & $1,357 \pm 46$ & $781 \pm 29$ & $1.43 \pm 0.02$ & $1.99 \pm 0.03$ \\
$40(3,760)$ & $209 \pm 27$ & $244 \pm 9$ & $1,308 \pm 61$ & $782 \pm 23$ & $1.42 \pm 0.02$ & $1.96 \pm 0.02$ \\
\hline
\end{tabular}

${ }^{\mathrm{a}} K=$ weight $(\mathrm{g}) /$ length $(\mathrm{mm})^{3}$. 
TABLE 2.-Composition (percent of dry matter) of the experimental diets fed to phase-III sunshine bass.

\begin{tabular}{|c|c|c|c|c|}
\hline \multirow[b]{2}{*}{ Ingredient } & \multirow[b]{2}{*}{ International feed number ${ }^{a}$} & \multicolumn{3}{|c|}{$\operatorname{Diet}^{\mathrm{b}}$} \\
\hline & & 1 & 2 & 3 \\
\hline Menhaden meal $^{\mathrm{c}}$ & $5-02-000$ & 20.00 & 23.00 & 26.50 \\
\hline Blood meal, spray dried & $5-00-381$ & 5.25 & 6.75 & 8.00 \\
\hline Poultry by-product meal & $5-03-798$ & 5.25 & 6.75 & 8.00 \\
\hline Wheat middlings & $4-05-205$ & 27.00 & 22.00 & 15.00 \\
\hline Corn grain & $4-02-935$ & 24.55 & 17.55 & 13.55 \\
\hline Corn gluten meal & $5-28-242$ & 5.25 & 6.75 & 8.00 \\
\hline Soybean meal, $48 \%$ & $5-04-604$ & 5.25 & 6.75 & 8.00 \\
\hline Monocal ( $21 \%$ phosphate) & 6-01-080 & 1.00 & 1.00 & 1.00 \\
\hline Vitamin premix ${ }^{\mathrm{d}}$ & & 0.25 & 0.25 & 0.25 \\
\hline Stay-C $35^{\mathrm{e}}$ & & 0.05 & 0.05 & 0.05 \\
\hline Choline chloride $(60 \%)$ & & 0.05 & 0.05 & 0.05 \\
\hline Mineral premix ${ }^{\mathrm{f}}$ & & 0.10 & 0.10 & 0.10 \\
\hline Menhaden oil & 7-08-049 & 5.00 & 8.00 & 11.50 \\
\hline Total & & 100.00 & 100.00 & 100.00 \\
\hline
\end{tabular}

a Source: NRC 1993.

${ }^{\mathrm{b}}$ Diet 1 had $32 \%$ crude protein (CP; 3,000 kcal energy/kg); diet 2 had 36\% CP (3,360 kcal/kg); and diet 3 had $40 \% \mathrm{CP}(3,760 \mathrm{kcal} / \mathrm{kg})$.

${ }^{\mathrm{c}}$ Special Select (Omega Protein, Inc., Houston, Texas).

${ }^{\mathrm{d}}$ U.S. Fish and Wildlife Service (USFWS) vitamin premix \#30 (U.S. Pharmaceutical [USP] units, or International units [IU], or g/kg premix): retinyl palmitate, 1,650 USP; cholecalciferol, $110 \mathrm{IU}$; DL- $\alpha$-tocopherol acetate, $88 \mathrm{IU}$; menadione sodium bisulfate, $2.8 \mathrm{~g}$; niacin, 0.06 g; riboflavin, $0.014 \mathrm{~g}$; pyrodoxine $\mathrm{HCl}, 7.7 \mathrm{~g}$; thiamine, $8.8 \mathrm{~g}$; $\mathrm{D}-\mathrm{Ca}$ pantothenate, $0.026 \mathrm{~g}$; biotin, $0.9 \mathrm{~g}$; folic acid, $2.2 \mathrm{~g}$; and vitamin $\mathrm{B}_{12}, 0.006 \mathrm{~g}$.

e Roche Vitamins, Inc., Parsippany, New Jersey.

${ }^{\mathrm{f}}$ USFWS mineral premix \#3 (g/kg premix): calcium, 0.037; copper, 1.54; iodine, 10; iron, 0.6; magnesium, 0.22; manganese, 22.9; phosphorus, 0.0002; selenium, 0.0004; sodium, 0.0005; sulfur, 0.75; and zinc, 75 .

weights (mean \pm SE) at harvest also were not significantly different, reaching $726 \pm 20,781 \pm 29$, and $782 \pm 23 \mathrm{~g}$ for fish fed 32-, 36-, and 40\%-CP diets, respectively (Table 1$)$. The dressed percentage based on 25 fish from each pond did not vary relative to nutrient density and averaged approximately $80 \%$ of whole-fish weight. Feed conversion ratios (mean \pm SE) were $3.0 \pm 0.2,2.8 \pm 0.1$, and $2.6 \pm 0.6$ and protein conversion ratios were $0.97 \pm 0.07,1.01 \pm$ 0.03 , and $1.04 \pm 0.02$ for the $32-, 36-$, and $40 \%-\mathrm{CP}$ diets, respectively; these values were not significantly different. The hepatosomatic index ([liver weight/fish

TABLE 3.- Proximate composition (percent of dry matter) of diets fed to phase-III sunshine bass. See Table 2 for a description of experimental diets.

\begin{tabular}{lrrr}
\hline & \multicolumn{3}{c}{ Experimental diet } \\
\cline { 2 - 4 } \multicolumn{1}{c}{ Component } & \multicolumn{1}{c}{1} & \multicolumn{1}{c}{3} \\
\hline${\text { Crude protein }(\mathrm{CP})^{\mathrm{a}}}^{\mathrm{n}}$ & 34.3 & 36.5 & 41.0 \\
Crude lipid $^{\mathrm{b}}$ & 12.3 & 14.7 & 17.0 \\
Ash $^{\mathrm{c}}$ & 7.5 & 7.3 & 8.1 \\
Crude fiber $^{\mathrm{d}}$ & 2.5 & 2.2 & 1.7 \\
Nitrogen-free extract $^{\mathrm{e}}$ & 33.4 & 27.9 & 22.2 \\
Moisture & 10.0 & 10.0 & 10.0 \\
Digestable energy : protein ratio & 9.3 & 9.3 & 9.3 \\
Dietary energy (kcal/kg feed) & $3,000.0$ & $3,360.0$ & $3,760.0$
\end{tabular}

\footnotetext{
${ }^{a}$ Kjeldahl $\mathrm{N} \times 6.25$.

${ }^{\mathrm{b}}$ Folch et al. (1957).

c Muffle furnace.

d Acid hydrolysis.

e Estimation based on subtraction.
}

weight] $\times 100$ ) averaged nearly 4 and was not significantly affected by dietary treatment. Sunshine bass were grouped into five size-classes (based on industry values) per pond for comparative purposes (Tables 5, 6). Variation among treatment groups was not significantly different except that the $36 \%-\mathrm{CP}$ group contained significantly more fish within the 9081,135-g size-class than did the other two treatments. Subsequent revenue generated from projected sales of fish were also unaffected by dietary treatment. Feed costs were $\$ 0.447, \$ 0.493$, and $\$ 0.541$ per kilogram for the 32-, 36-, and 40\%-CP diets, respectively, resulting in a production cost attributable to feed of $\$ 1.34, \$ 1.38$, and $\$ 1.41$ per kilogram of gain, respectively.

\section{Discussion}

Growth of phase-III sunshine bass in this study was similar regardless of dietary treatment, indicating that reduction of dietary protein is a viable feeding strategy to use during phase-III sunshine bass production. Our production results are similar to those obtained by D'Abramo et al. (2000) with phase-III fish, although in the present study fish fed $32 \%$-CP diets performed as well as those fed $36 \%$-CP diets. Similar results were obtained by Kasper and Kohler (2004) when feeding diets containing $32 \% \mathrm{CP}$ and $355 \mathrm{kcal} / 100 \mathrm{~g} \mathrm{CP}$ to phase-III sunshine bass that were reared in an indoor recirculation system. Our results are also comparable to observations made in studies of channel catfish Ictalurus punctatus wherein similar feeding strategies 
TABLE 4.- Mean food consumption, production gain, survival, dressed percentage, feed conversion ratio (FCR), protein conversion ratio (PCR), and hepatosomatic index (HSI) of sunshine bass fed 32-, 36-, and 40\%-crude-protein (CP) diets with an energy: protein ratio of $9.3 \mathrm{kcal}$ energy $/ \mathrm{g} \mathrm{CP}$. Values $(n=50)$ are means $( \pm \mathrm{SE})$ of four ponds. Column values were not significantly different among treatments $(P<0.05)$.

\begin{tabular}{cccccccc}
\hline $\begin{array}{c}\text { \% CP } \\
\text { (kcal energy/kg) }\end{array}$ & $\begin{array}{c}\text { Food fed } \\
\text { (kg/ha) }\end{array}$ & $\begin{array}{c}\text { Production gain } \\
\text { (kg/ha) }\end{array}$ & $\begin{array}{c}\text { Survival } \\
(\%)\end{array}$ & $\begin{array}{c}\text { Dressed } \\
\text { percentage }^{\mathrm{a}}\end{array}$ & FCR $^{\mathrm{b}}$ & PCR $^{\mathrm{c}}$ & HSI $^{\mathrm{d}}$ \\
\hline $32(3,000)$ & $8,495 \pm 421$ & $2,851 \pm 300$ & $93 \pm 11$ & $80 \pm 2$ & $3.0 \pm 0.2$ & $0.97 \pm 0.07$ & $4.0 \pm 0.01$ \\
$36(3,360)$ & $8,149 \pm 211$ & $2,895 \pm 96$ & $88 \pm 9$ & $80 \pm 1$ & $2.8 \pm 0.1$ & $1.01 \pm 0.03$ & $4.0 \pm 0.02$ \\
$40(3,760)$ & $7,711 \pm 125$ & $2,953 \pm 71$ & $90 \pm 2$ & $81 \pm 1$ & $2.6 \pm 0.1$ & $1.04 \pm 0.02$ & $3.9 \pm 0.01$ \\
\hline
\end{tabular}

\footnotetext{
${ }^{\mathrm{a}}$ Weight of fish with gills and vicera removed/total fish weight.

${ }^{\mathrm{b}}$ Weight of food fed/fish weight gained.

${ }^{\mathrm{c}}$ Protein of food fed/fish protein gained.

${ }^{\mathrm{d}}$ (Liver weight $\left.[\mathrm{g}] \times 100\right) /$ body weight of fish $(\mathrm{g})$.
}

and techniques were used (Robinson and Li 1998, 1999; Li et al. 2003). Robinson and Li (1999, 2003) found that channel catfish still exhibited maximum growth regardless of stocking density when they were fed a $28 \%$-CP diet to satiation.

To maintain the E:P ratio at $9.3 \mathrm{kcal} / \mathrm{g} \mathrm{CP}$ in this study, our $40 \%$-CP diet contained approximately $17 \%$ crude lipid (11.5 g), which is energy dense for hybrid striped bass and which may have negatively affected the growth of phase-III fish in this study. Elevated dietary lipids may facilitate triglyceride and glycogen accumulation in hepatic tissues, resulting in impaired liver function and reduced fish growth, and have been of significant concern in studies of coolwater species, including sunshine bass (Nematipour and Gatlin 1992a, 1992b, 1993; Webster et al. 1995) palmetto bass (white bass $\delta \times$ striped bass q) Brown et al. 1993), and yellow perch Perca flavescens (Brown et al. 1996), as well as coldwater species such as rainbow trout Oncorhynchus mykiss (Yang and Dick 1994) and brown trout Salmo trutta (Arzel et al. 1994). This often results in elevated liver weight, which may be an indication of compromised fish health. Hepatosomatic index results from our study are in agreement with those of Webster et al. (1995), Keembiyehetty and Wilson (1998), and D'Abramo et al. (2000), all of whom used diets containing similar E:P ratios. However, our hepatosomatic index values are somewhat higher than those reported by Nematipour et al.
(1993). Considering the $K$ (Table 1) and hepatosomatic index (Table 4) of fish in this study, the elevated dietary lipid content did not appear to negatively impact fish growth performance. However, we did not measure the total liver lipid content, nor was the fatty acid composition evaluated; these factors should be considered in future studies investigating diets of this nature in hybrid striped bass production.

It is important to note that excessive individual size variation within a pond is often exacerbated by feeding low-energy feeds, especially when fish are not fed to satiation (Robinson and Li 1998, 1999). Therefore, care must be taken when evaluating the effectiveness of feeding strategies that use low-protein, low-energy diets, especially for carnivorous fish such as hybrid striped bass. Often, feed consumption will be inversely correlated with concentrations of dietary protein and energy, and subsequent weight gain exhibited by fish will be based on among-treatment differences in the amount of feed consumed. If variation within production ponds becomes significant or if feed prices are highly volatile, profits may be reduced since not all fish will have reached market size. At the time this study was conducted, the differences in feed cost per pound of fish produced were not significantly different between treatments and furthermore did not exhibit a significantly negative impact on the overall production characteristics of this study.

In studies investigating reduced protein and energy

TABLE 5.-Size variation and harvest weights of sunshine bass fed 32-, 36-, and 40\%-crude-protein (CP) diets with an energy : protein ratio of $9.3 \mathrm{kcal}$ energy/g CP. Values are means ( \pm SEs) of four ponds. Means with the same letter within each column were not significantly different $(P<0.05)$.

\begin{tabular}{|c|c|c|c|c|c|c|}
\hline \multirow[b]{2}{*}{$\% \mathrm{CP}(\mathrm{kcal}$ energy $/ \mathrm{kg})$} & \multicolumn{5}{|c|}{ Mean size distribution $(\mathrm{kg} / \mathrm{ha})^{\mathrm{a}}$} & \multirow[b]{2}{*}{ Total harvest weight $(\mathrm{kg} / \mathrm{ha})$} \\
\hline & 1 & 2 & 3 & 4 & 5 & \\
\hline $32(3,000)$ & $82 \pm 31 \mathrm{z}$ & $1,295 \pm 251 \mathrm{z}$ & $2,834 \pm 145 \mathrm{z}$ & $429 \pm 113 x$ & & $4,202 \pm 205 \mathrm{z}$ \\
\hline $36(3,360)$ & $54 \pm 0 \mathrm{z}$ & $816 \pm 209 \mathrm{z}$ & $2,542 \pm 140 \mathrm{z}$ & $1,723 \pm 324 \mathrm{z}$ & & $4,253 \pm 195 \mathrm{z}$ \\
\hline $40(3,760)$ & $55 \pm 1 \mathrm{z}$ & $998 \pm 240 \mathrm{z}$ & $2,856 \pm 105 \mathrm{z}$ & $981 \pm 347 \mathrm{y}$ & $148 \pm 5 \mathrm{z}$ & $4,178 \pm 24 \mathrm{z}$ \\
\hline
\end{tabular}

a Based on five industry standards for marketable-size sunshine bass: (1) very small (340-454 g); (2) small (454-680 g); (3) medium (680-908 g);

(4) large (908-1,135 g); (5) jumbo (>1,135 g). 
TABLE 6.- Revenue generation (U.S. dollars/ha) for various sizes of sunshine bass fed 32-, 36-, and 40\%-crude-protein (CP) diets with an energy : protein ratio of $9.3 \mathrm{kcal}$ energy $/ \mathrm{g} \mathrm{CP}$. Values are means ( \pm SDs) of four ponds. Means with the same letter within each column are not significantly different $(P<0.05)$. See Table 5 for size-class descriptions.

\begin{tabular}{|c|c|c|c|c|c|c|}
\hline \multirow[b]{2}{*}{$\%$ CP (kcal energy/kg) } & \multicolumn{5}{|c|}{ Size-class } & \multirow[b]{2}{*}{ Total revenue } \\
\hline & 1 & 2 & 3 & 4 & 5 & \\
\hline $32(3,000)$ & $89 \pm 33 z$ & $1,502 \pm 291 \mathrm{z}$ & $2,486 \pm 179 \mathrm{z}$ & $558 \pm 148 \mathrm{y}$ & & $5,613 \pm 149 \mathrm{z}$ \\
\hline $36(3,360)$ & $58 \pm 0 \mathrm{z}$ & $946 \pm 242 \mathrm{z}$ & $3,126 \pm 86 \mathrm{z}$ & $2,240 \pm 421 \mathrm{z}$ & & $6,328 \pm 217 \mathrm{z}$ \\
\hline $40(3,760)$ & $60 \pm 1 \mathrm{z}$ & $1,146 \pm 278 \mathrm{z}$ & $3,513 \pm 129 \mathrm{z}$ & $1,276 \pm 451 \mathrm{x}$ & $201 \pm 7 \mathrm{z}$ & $6,066 \pm 275 \mathrm{z}$ \\
\hline
\end{tabular}

in fish feeds, size variation within dietary treatments may be exacerbated and can negatively influence overall production. In the present study, variation in individual fish size within each treatment was observed in each pond (Table 5). Therefore, determining the profits resulting from sale of fish seemed warranted, especially since fish command graded market values that increase with increasing size. When market prices were applied to the production levels achieved in this study, no significant differences from dietary treatment were observed (Table 6). Although the $36 \%$-CP ponds contained significantly more fish within the 9081,135 -g size-class than did other ponds and although $32 \%$-CP ponds contained more fish within the 454 680 -g size-class, the revenue generated from these ponds was not significantly different. The size variation within ponds turned out to exert minimal impact on the total production of fish in this study; moreover, total revenue calculated from sales of fish within these categories was not significantly different with respect to treatment. Our results suggest that feeding diets containing 32\%- or 36\%-CP with an E:P ratio of 9.3 $\mathrm{kcal} / \mathrm{g}$ protein during the latter portion of phase-III sunshine bass grow out may be possible without sacrificing time to market or profits.

Although survival for all dietary treatments was high (averaging nearly 90\%), fish fed the $32 \%-\mathrm{CP}$ diet $(3,000 \mathrm{kcal} / \mathrm{kg})$ exhibited the most size variation overall among treatments. Despite the lack of significant differences in our study, the 32\%-CP diet (9.3 $\mathrm{kcal} / \mathrm{g} \mathrm{CP}$ ) may be marginally nutrient limiting for sunshine bass entering phase-III production, and some fish may not have exhibited maximal growth on this diet. Therefore, reserving the $32 \%$-CP diets until fish are slightly larger may serve as a superior feeding strategy than merely switching to a $32 \%$-CP diet upon inception of phase III. Further study of phase feeding strategies is clearly warranted. Provision of more dietary energy might increase protein sparing to allow for $30 \%$ - or even $28 \%$-CP feeds to be considered in phase-III production.

Variation exhibited by fish that were fed the $32 \%-\mathrm{CP}$ diet might be an artifact of feeding frequency. Liu and Liao (1999) observed that sunshine bass fed three meals per day exhibited less size variation in a study of feeding regimens for juvenile fish (mean individual weight $=12.5 \mathrm{~g}$ ). The variation in length and weight of phase-III sunshine bass fed twice daily to satiation in a recirculation system (Kasper and Kohler 2004) was less than that of fish used in the current pond study. Additionally, Jobling (1983) suggested that the incidence of reduced growth seen in Arctic char Salvelinus alpinus is an artifact of social hierarchy and may be decreased when fish are fed frequently. Due to the cannibalistic nature of younger sunshine bass, feeding fish more than once daily may effectively minimize size variation.

Feed conversion ratios in this study were similar to those of pond-reared sunshine bass fed similar diets (D'Abramo et al. 2000) and sunshine bass fed practical diets under caged conditions (Webster et al. 1995, 2001); however, values were notably higher than those obtained in feeding trials with fish reared in indoor recirculation systems (Nematipour et al. 1992a, 1992b; Gaylord and Gatlin 2000; Rudacille and Kohler 2000; Kasper and Kohler 2004). This contrast is probably a result of fluctuations in summer water temperatures in ponds relative to the more stable temperatures often achieved in indoor water reuse systems. D'Abramo et al. (2000) noted that prolonged water temperatures exceeding $30^{\circ} \mathrm{C}$ adversely affected the feed conversion of phase-III sunshine bass reared in ponds. Similar observations have been made for indoor culture (Keembiyehetty and Wilson 1998). The optimal temperature for sunshine bass is reportedly near $26^{\circ} \mathrm{C}$ (Hodson 1989).

$\mathrm{Wu}$ (1995) estimated that as much as 95\% of nitrogenous wastes in aquaculture environments are contributed by feed. McGoogan and Gatlin (1999) observed that increases in nitrogen excretion occurred when diets containing excessive energy were fed to red drum Sciaenops ocellatus. Because excessive dietary protein with respect to nonprotein energy may increase ammonia excretion in fish, the catabolism of dietary protein often results in nitrogen excretion from gills into the water and facilitates eutrophication (Kaushik and Cowey 1991). One concern about feeding lowerprotein, lower-energy diets is that increased feed 
consumption might contribute equal amounts of nitrogen to the aquatic system, resulting in enhancement of eutrophication. Hargreaves and Tucker (2005) have also recently discussed the sublethal effects of nitrogenous compounds within the pond environment; these effects include reduced growth, poor feed conversion, and reduced immunocompetence, all of which are detrimental to hybrid striped bass pond production. Those authors specifically targeted the source of ammonia excretion (ultimately from food) as a primary source of pond nitrogen. During summer months, photosynthesis would buffer against dramatic rises in nitrogen levels within ponds. However, nitrogen reductions from feed would tend to reduce nitrogen levels during late afternoons, which should improve water quality and which should be especially beneficial as water temperatures decrease during fall and winter months and during wintering (i.e., when bacterial photosynthesis is reduced). It is therefore tempting to speculate that the reduction in pond ammonia levels by administering lower-protein, lowerenergy feeds might well reduce the total ammonia nitrogen that is contributed to the culture environment. Although total ammonia nitrogen, nitrite-nitrogen, and nitrate-nitrogen levels did not exhibit significant fluctuations during this experiment, further study will be needed to determine the absolute effects of reducedprotein feeds on pond nitrogen levels.

Feed costs still constitute the largest annual variable cost in aquaculture production and represent an area where highly effective reductions in overall production cost may be achieved through close adherence to sound feeding practices and proper application of low-cost, nutritionally efficacious feeds (Carlberg et al. 2000). Although the market price of feeds often substantially affects production costs, the bottom line of production is often the price per kilogram of fish produced and subsequent generation of revenue, especially in markets where fish are sold whole or live. Considering the similarity in fish production among the evaluated treatments and the significant difference in average feed cost, a closer examination of cost per kilogram of fish produced seems warranted. Feed cost per kilogram for diets used in this study were $\$ 0.447, \$ 0.493$, and $\$ 0.541$ for the 32-, 36-, and 40\%-CP feeds, respectively, resulting in production costs attributable to feed of $\$ 1.34, \$ 1.38$, and $\$ 1.41$ per kilogram, respectively. When these numbers were applied to the densities in this study, an estimated savings of approximately $\$ 599.00$ per hectare was partially achieved by the use of 32- and 36\%-CP feeds. Accordingly, given the results of the present study, utilization of reduced-protein and reduced-energy diets during phase-III sunshine bass production appears to be a viable alternative feeding strategy to currently practiced culture methods.

\section{Acknowledgments}

We thank Denny Hughes, William Poly, Steve Mueller and Sheryl Broadie for their advice and assistance during the course of this study. Funding was provided by the North Central Regional Aquaculture Center under grant number 2001-38500-10369.

\section{References}

Arzel, J., F. X. Martinez Lopez, R. Metailler, G. Shephan, M. Viau, G. Gandemer, and J. Guillaume. 1994. Effect of dietary lipid on growth performance and body composition of brown trout (Salmo trutta) reared in seawater. Aquaculture 123:361-375.

Brown, P. B. 1995. Using whole-body amino acid patterns and quantitative requirements to rapidly develop diets for new species such as hybrid striped bass (Morone saxatilis $\times M$. chrysops). Journal of Applied Ichthyology 11:342346.

Brown, P. B., K. Dabrowski, and D. L. Garling. 1996. Nutrition and feeding of yellow perch (Perca flavescens). Journal of Applied Ichthyology 12:171-174.

Brown, P. B., M. E. Griffin, and M. R. White. 1993. Experimental and practical diet evaluations with juvenile hybrid striped bass. Journal of the World Aquaculture Society 24:80-89.

Carlberg, J. M., J. C. Van Olst, and M. J. Massingill. 2000. Hybrid striped bass: an important fish in U.S. aquaculture. Aquaculture Magazine 26(5):21-25.

D'Abramo, L. R., C. L. Ohs, and J. B. Taylor. 2000. Effects of reduced levels of dietary protein and menhaden fish meal on production, dressout, and biochemical composition of phase-III sunshine bass, Morone chrysops $q \times M$. saxatilis $\delta$, cultured in earthen ponds Journal of the World Aquaculture Society 31:316-325.

Folch, J., M. Lees, and G. H. Sloan-Stanley. 1957. A simple method for the isolation and purification of total lipids from animal tissues. Journal of Biological Chemistry 226:497-509.

Gallagher, M. L. 1997. Apparent digestibility coefficients for some carbohydrates in diets for hybrid striped bass Morone saxatilis $\times M$. chrysops. Journal of the World Aquaculture Society 28:429-431.

Gaylord, G. T., and D. M. Gatlin. 2000. Dietary lipid but not L-carnitine affects growth performance of hybrid striped bass (Morone chrysops $\times$ M. saxatilis). Aquaculture 190:237-246.

Griffin, M. E., P. B. Brown, and A. L. Grant. 1992. The dietary lysine requirement of juvenile hybrid striped bass. Journal of Nutrition 122:1332-1337.

Griffin, M. E., M. R. White, and P. B. Brown. 1994a. Total sulfur amino acid requirement and cysteine replacement value for juvenile hybrid striped bass (Morone saxatilis $\times$ M. chrysops). Journal of Comparative Biochemistry and Physiology 108:423-429.

Griffin, M. E., K. A. Wilson, and P. B. Brown. 1994b. Dietary arginine requirement of juvenile hybrid striped bass. Journal of Nutrition 124:888-893. 
Griffin, M. E., K. A. Wilson, M. R. White, and P. B. Brown. 1994c. Dietary choline requirement of juvenile hybrid striped bass. Journal of Nutrition 124:1685-1689.

Hargreaves, J. A., and C. S. Tucker. 2005. Conditions associated with sublethal ammonia toxicity in warmwater aquaculture ponds. World Aquaculture 36(3):20-24.

Hodson, R. G. 1989. Hybrid striped bass biology and life history. Southern Regional Aquaculture Center, Publication 300, Raleigh, North Carolina.

Jobling, M. 1983. Effect of feeding frequency of food intake and growth of Arctic charr, Salvelinus alpinus L. Journal of Fish Biology 23:177-185.

Kasper, C. S., and C. C. Kohler. 2004. Use of finishing diets in indoor hybrid striped bass culture reduces production costs. Pages 507-513 in T. T. Rakestraw, L. S. Douglas, and G. J. Flick, editors. Proceedings of the 5th international conference on recirculating aquaculture. Virginia Tech University, Blacksburg.

Kaushik, S. J., and C. B. Cowey. 1991. Dietary factors affecting nitrogen excretion by fish. Pages 3-19 in C. B. Cowey and C. Y. Cho, editors. Nutritional strategies and aquaculture waste: proceedings of the first international symposium on nutritional strategies in management of aquaculture wastes. University of Guelph, Guelph, Ontario, Canada.

Keembiyehetty, C. N., and D. M. Gatlin. 1992. Dietary lysine requirement of juvenile hybrid striped bass (Morone chrysops $\times$ Morone saxatilis). Aquaculture 104:271277.

Keembiyehetty, C. N., and R. P. Wilson. 1998. Effect of water temperature on growth and nutrient utilization of sunshine bass (Morone chrysops $q \times$ Morone saxatilis ๙) fed diets containing different energy/protein ratios. Aquaculture 166:151-162.

Kohler, C. C. 2000. Striped bass and hybrid striped bass culture. Pages 898-907 in R. R. Stickney, editor. Encyclopedia of aquaculture. Wiley, New York.

Li, M. H., B. B. Manning, E. H. Robinson, and B. G. Bosworth. 2003. Effect of dietary protein concentration and stocking density on production characteristics of pond- raised channel catfish Ictalurus punctatus. Journal of the World Aquaculture Society 34:147-155.

Liu, F., and C. Liao. 1999. Effect of feeding regimen on the food consumption, growth, and body composition in hybrid striped bass Morone saxatilis $\times M$. chrysops. Fisheries Science 65:513-519.

McGoogan, B. B., and D. M. Gatlin, III. 1999. Dietary manipulations affecting growth and nitrogenous wastes production of red drum, Sciaenops ocellatus, I. Effects of dietary protein and energy levels. Aquaculture 178:333348.

NRC (National Research Council). 1993. Nutrient requirements of fish. National Academy Press, Washington, D.C.

Nematipour, G. R., and D. M. Gatlin. 1992a. Effects of dietary energy:protein ratio on growth characteristics and body composition of hybrid striped bass, Morone chrysops $\times$ Morone saxatilis. Aquaculture 107:359-368.

Nematipour, G. R., and D. M. Gatlin. 1992b. Effects of dietary carbohydrate:lipid ratio on growth characteristics and body composition of hybrid striped bass. Journal of the World Aquaculture Society 23:128-132.

Nematipour, G. R., and D. M. Gatlin. 1993. Effects of different lipid sources on growth and fatty acid composition of hybrid striped bass (Morone chrysops $\times$ M. saxatilis). Aquaculture 114:141-154.

Robinson, E. H., and M. H. Li. 2003. A practical guide to nutrition, feeds, and feeding of catfish. Mississippi Agricultural and Forestry Experiment Station, Bulletin 1041, Mississippi State.

Robinson, E. H., and M. H. Li. 1998. Comparison of practical diets with and without animal protein at various concentrations of dietary protein on performance of channel catfish Ictalurus punctatus raised in earthen ponds. Journal of the World Aquaculture Society 29:273-280.

Robinson, E. H., and M. H. Li. 1999. Evaluation of practical diets with various levels of dietary protein and animal protein for pond-raised channel catfish Ictalurus punctatus. Journal of the World Aquaculture Society 30:147153.

Rudacille, J. B., and C. C. Kohler. 2000. Aquaculture performance comparison of sunshine bass, palmetto bass, and white bass. North American Journal of Aquaculture 62:114-124.

Sullivan, J. A., and R. C. Reigh. 1995. Apparent digestibility of selective feedstuffs in diets for hybrid striped bass (Morone saxatilis $+9 \times$ Morone chrysops $\widehat{0}$ ). Aquaculture 138:313-322.

Volkman, E. T., C. C. Kohler, and S. T. Kohler. 2004. Assessment of floating vertical raceways for the culture of phase-II hybrid striped bass. North American Journal of Aquaculture 66:125-132.

Webster, C. D., L. G. Tiu, J. H. Tidwell, P. V. Wyk, and D. R. Howerton. 1995. Effects of dietary protein and lipid levels on growth and body composition of sunshine bass (Morone chrysops $\times$. M. saxatilis) reared in cages. Aquaculture 131:291-301.

Webster, C. D., K. R. Thompson, A. M. Morgan, and E. J. Grisby. 2001. Feeding frequency affects growth, not fillet composition, of juvenile sunshine bass Morone chrysops $\times$ M. saxatilis grown in cages. Journal of the World Aquaculture Society 32:79-88.

Wu, R. S. S. 1995. The environmental impact of marine fish culture: towards a sustainable future. Marine Pollution Bulletin 3:159-166.

Yang, X., and T. A. Dick. 1994. Arctic charr (Salvelinus alpinus) and rainbow trout (Oncorhynchus mykiss) differ in their growth and lipid metabolism in response to dietary poly unsaturated fatty acids. Canadian Journal of Fisheries and Aquatic Sciences 51:1391-1400. 